\title{
利根川上流域を対象とした渴水対策のための 力学的季節予測結果の利用に関する基礎的研究
}

\author{
PRELIMINARY STUDY OF THE USE OF THE DINAMICAL SEASONAL \\ PREDICTIONS IN THE UPSTREAM OF THE TONE RIVER BASIN FOR \\ DROUGHT MANAGEMENT
}

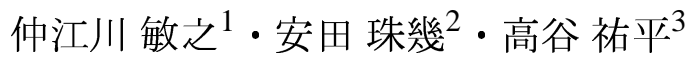 \\ Tosiyuki NAKAEGAWA, Tamaki YASUDA, and Yuhei TAKAYA \\ 1 正会員 博士 (工学) 気象研究所 主任研究官 (⿳亠口冖丁 305-0052 つくば市長峰 1-1) \\ 2 非会員 博士 (理学) 気象研究所 主任研究官 (⿳亠口了丁305-0052 つくば市長峰 1-1) \\ 3 非会員 学士 (理学) 気象庁 地球環境・海洋部 (广 100-8122 東京都千代田区大手町 1-3-4)
}

\begin{abstract}
This study preliminarily examines potential use of the dynamical seasonal prediction with an atmosphere-ocean coupled model for the drought management in the upstream of the Tone River basin. First, linkage between water storage in reservoirs for August and six accumulated-value predictors as precursor is revealed based on the observation data with non-parametric correlation test. In addition, correlation between drought and El Niño and Southern Oscillation phenomena years is examined to be not significant. The ensemble mean of the dynamical seasonal prediction outputs satisfactorily captures the drought years. This result suggests that the dynamical seasonal prediction may provide significant information about improvement in the cost-effectiveness of the the weather modification operations to practitioners.
\end{abstract}

Key Words: dynamical seasonal prediction, drought management, the Tone River basin, ENSO, weather modification

\section{1. はじめに}

日本の水資源需要量の将来見通しについては, 人口減 少傾向による需要減少が見込まれるが, その一方で自 然本来が持つ気候変動や人間活動が原因の地球温暖化 による気候変化によって, 降水量に関する不確定性が高 まっており ${ }^{1)}$, 水資源賦存量が大きく変化する可能性が 高い. 従って, 今後水資源の需給バランスが変化するこ とは, 想像に難くない. また, 温暖化に伴う気候変動の結 果, 平年值のみならず, 渇水頻度の上昇 ${ }^{2)}$ や渇水被害の 増加が懸念されている.

首都圈の水瓶と呼ばれる, 利根川上流域における取水 制限は, 過去 30 年で夏季に 9 回, 冬季に 2 回あり, 3 年 に 1 度程度起きていることになる. 渴水対策としては, ダム等の施設設置やその効果的な運用管理による貯水 量の増加が,これまで行われてきた. しかし, 施設設置 による水資源開発は大きく進み, 今後大規模な開発は望 めない.こうした従来の水資源開発とは異なる手法とし て, 天気を改変することにより人為的に降水量を増加さ せる,いわゆる人工降雨・降雪技術がある.

気象研究所と国土交通省利根川ダム統合管理事務所 による共同研究が, 1994 年から 2002 年の 14 年間に亘
り行われ, 冬季の山岳性降雪雲を対象に航空機シーディ ング実験や非静力学モデルによる数值実験が行われた 3,4).この結果によると, 理想的なシーディングが行われ れば,一冬で降雪量を 30〜 40\%増加させる可能性がある ことが示されている ${ }^{5}$.

冬季の山岳性降雪雲を対象にしたシーディングは技 術的にある程度確立しているが, 実用化のためには, 単 に降雪量の増加に留まらず, 水資源量の増加として評価 されなければならないし, 費用対効果の検討も必要であ る. 例えば, 人工降雪を行い, 融雪水により春先の水資 源量を増加させてたとしても, その年が非渇水年であれ ば, 夏季には不要な水資源は放流されてしまうので, 人 工降雪による渇水対策は結果的に無意味なものとなっ てしまう。

もし, 冬季に予めその年の夏季の水資源量予測が可能 であれば, もっと控えめに, 定性的な傾向だけでも予測 が可能であれば, 人工降雪をより効率的に行う可能性が ある. そこで, 本研究では, 首都圈の夏季渴水対策とし て, 利根川上流域で冬季に人工降雪による水資源確保を 効率的に行うための基礎研究を, 観測值と全球大気一海 洋結合モデルを用いた力学的な季節予測実駼結果をも とに行った. 


\section{2. データ, モデルと実験, 解析方法}

\section{(1) 観測データ}

本研究で用いた観測データは, 放流量, 貯水量, 流域降 水量, 渇水基準点流量 (栗橋), 日照率, 気温の 6 つのデー タである. データ期間は 1994 年から 2005 年までで, 利 根川上流 8 ダムと流域の平均值である. 日単位の元デー タを月平均して利用した。

\section{(2) モデルと実験}

季節予測実験に用いたモデルは, 気象庁で 2008 年度 中に El Niño 予測モデルとして用いられる大気-海洋結 合モデル (CGCM) である. 大気モデルは気象庁統一全 球大気モデルで, 水平解像度は約 $200 \mathrm{~km}$ (三角形切断・ 線形格子 TL95) で, 鉛直 40 層である. 海洋モデルは, 気 象研究所共用海洋大循環モデルで, 水平解像度は東西 1 度, 南北は赤道付近で 0.3 度, 中高緯度で 1 度となる可 変格子, 鈆直方向は 50 層で, 5000m までを表現してい る ${ }^{6)}$. 陸面水文過程は, Simple Biosphere モデル (Sib) を 用いており ${ }^{7)}$, 鉛直 1 次元の地表面と土壌内での熱水移 動, 地表面での積雪融雪過程を表現している.

季節予測実験は, 予測期間が 7 ケ, アンサンブル数 は 5 メンバーである. 1, 4, 7, 10 月の各月末 5 日の大気, 海洋の状態を各メンバーの初期值とした. 大気は日本再 解析-25 年 ${ }^{8)}$ の, 海洋は気象研で開発されたデータ同化 システム 9) からの出力を用いた. 実験期間は 1979 年か ら 2006 年までの 28 年である. 本研究では 1 月月末開 始のアンサンブル実験結果 (2-8月の予測) を用いた.

図-1に利根川流域周辺での大気モデル格子を示す.上 に述べたように, モデルの解像度は $200 \mathrm{~km}$ 格子で, 利根 川全流域面積よりも大きく, 上流域は 1 グリッドに収ま る. 本研究では, 利根川上流域を含む 1 グリッドのみを 解析対象とする.この図から明らかなように, 解析対象 とするグリッドには千曲川流域, 天竜川上流流域も含ま れており,これらの流域を対象とする場合でも, 以下で 述べるモデルの結果は, そのまま当てはまる.

\section{(3) 解析方法}

観測值については, 以下の手法を用いた. まず, その年 の渴水の程度は 8 月の貯水量が表すと考え, 8 月貯水量 と他の観測值との相関の有無をノンパラメトリックな Mann-Kendal の順位相関を用いて調べた. 状態量の貯水 量は, 観測時点までのフラッスの総和と関係があるので, 全てのデータを 8 月から遡って積算した各月のデータ セットを以下の式に従って作成した。

$$
x_{m, y}=\sum_{j=m}^{8} a_{j, y}
$$

ここで, $x_{m, y}$ は $y$ 年 $m$ 月から 8 月までの積算值, $a_{j, y}$ は $y$ 年 $j$ 月の観測值である。このようにして得られた值を, 貯水量と共に予測子とした. 以上の準備の下, 毎年 8 月 貯水量と同年 $\mathrm{m}$ 月の予測子 $x_{m, y}$ の相関関係を, $6 \supset$ 観

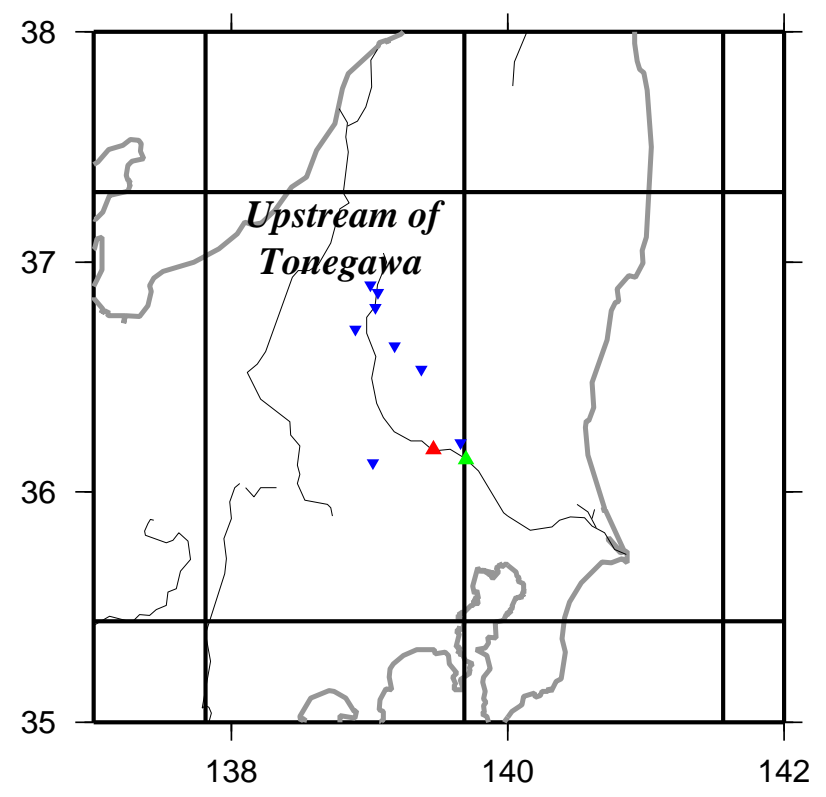

図-1 利根川流域周辺での CGCM の大気モデルグリッド格子 の配置. 水色 $\nabla$ がダム, 緑色 $\triangle$ が栗橋流量観測点, 赤色 $\triangle$ が利根大堰の位置を示している.

測データ $\times 7$ ケ $=42$ 通りについて調べた.

通常, 8 月の渇水状況の前兆指標 (予測子) を調べる場 合, 前兆現象から 8 月までのデータを使わないことが, 前兆指標としての必須条件であるが,この研究では, 8 月 までの季節予測結果が利用できることを前提に, 8 月の 貯水量に, より強い影響のある前兆現象から 8 月までの 積算量を前兆指標として用いている.

\section{3. 結果}

\section{(1) 8 月貯水量と予測子の相関関係}

ここでは, 8 月貯水量と予測子の相関関係について述 べる. 両側検定 5\%の有意水準で, 相関があるかないか を判定した。

図-2に 8 月貯水量と 6 つの予測子の Mann-Kendal の 順位相関解析の結果を示す. 相関関係は Mann-Kendall の順位相関検定で調べた. 縦軸は Kendall の $\tau$ で, $-1 \sim 1$ の值を取り, 絶対值が大きいほど, 相関が高い. 8 月貯留 量と積算貯留量の相関は, 2 月から 7 月まで, いずれも 有意であった. 従って, 貯留量は積算しても相関が高く, 低周波の変動をしていることが示唆される. 力学的な予 測では, 季節平均程度までは, 時間平均を長くした方が 予測可能性が高いことが知られているので, 積算とほぼ 等価な長期の時閒平均と相関が高いことは予測の利用 にとって好ましい結果である.

次に積算降水量との関係をみると, 8 月貯水量と有意 な相関がある月は $2,3,6,7,8$ 月で, 春の 4,5 月には有 意な相関が無い. 一旦, 相関が有意でなくなり, 再び, 冬 季の 2,3 月から 8 月までの積算降水量では 8 月貯水量 に相関があるということは, 冬季の降雪が 8 月貯水量に 重要であることを示唆している. 実際, 2,3月各々の月降 


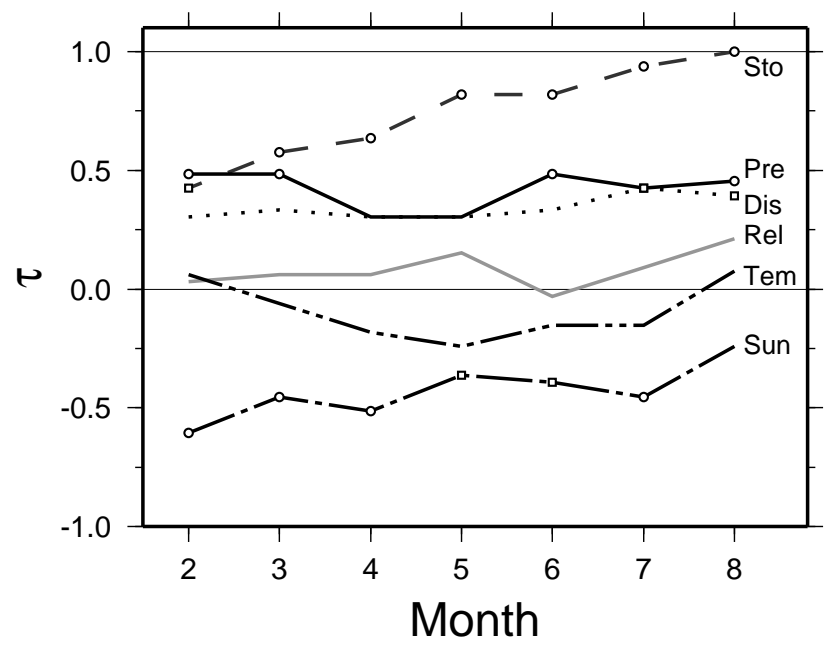

図-28 月貯水量と関連観測量の積算值の相関関係. 図中の実 線は降水量 (Pre), 破線は貯水量 (Sto), 点線は放流量 (Rel), 灰色実線は河川流量 (Dis), 二点鎖線は気温 (Tem), 一点 鎖線は日照率 (Sun) を表している.

水量と 8 月貯水量の相関を調べると有意で, 流域水資源 の半分を融雪水に依存しているという既往の推定もあ るので, 半年前に当たる 2,3 月からの積算降水量と 8 月 貯水量の相関係数が高くなっていると考えられる.

夏季の $6,7,8$ 月に相関が高いことは, 直感的にも妥当 である. 梅雨開始時期から盛夏までの $6,7,8$ 月は降水 量が多い季節で, この時期の降水量は, 時閒遅れなく, ダ 么貯水量に大きな影響を持つ.この期間に十分な雨があ れば, それ以前の降水量が少なくても, 8 月貯水量が少 なくなることは無いので, この期間からの積算降水量と 8 月貯水量の相関係数は高くなっている.

積算日照率と 8 月貯水量の相関は, 2 月から 7 月まで 全ての月で有意な負の相関関係がある. 日照率は, 雲が 日射を遮蔽しない割合なので, 雲量と直接的に関係して おり,その結果, 降水量とも相関が高いという関係が現 れている.この結果は, 人工降雨・降雪を行う場合, シー ディングに適した雲が渇水年には少ない可能性を示唆 している. 全ての雲がシーディングに適している訳では ないので, 村上ら ${ }^{10)}$ が行ったような雲物理学的な観点 から, 詳細な検討が必要である.

積算流量との関係は 7,8 月と直近では相関があるが, それ以前との関係は無い. これは, 基潐流量観測点が下 流に位置し, しかも利根大堰等の取水がなされた後であ るからであろう.また、積算流量と貯留量の因果関係か らみると、貯留量が少ない (多い) と、結果的に積算流 量が少なく(多く) なる訳で、関係があったとしても予 測子には馴染まない。

気温とはどの月に対しても有意な相関が見られなかっ た. 気温が高ければ晴天日が多く, 降水量が少ないと推 論できるが, 日本の夏季の気温は日射のみならず, 太平 洋高気圧がもたらす暖気も主要因のため, 上述のような 推論は当てはまらない. その結果, 8 月貯水量と直近の 積算気温とさえも相関が有意でなくなっている.

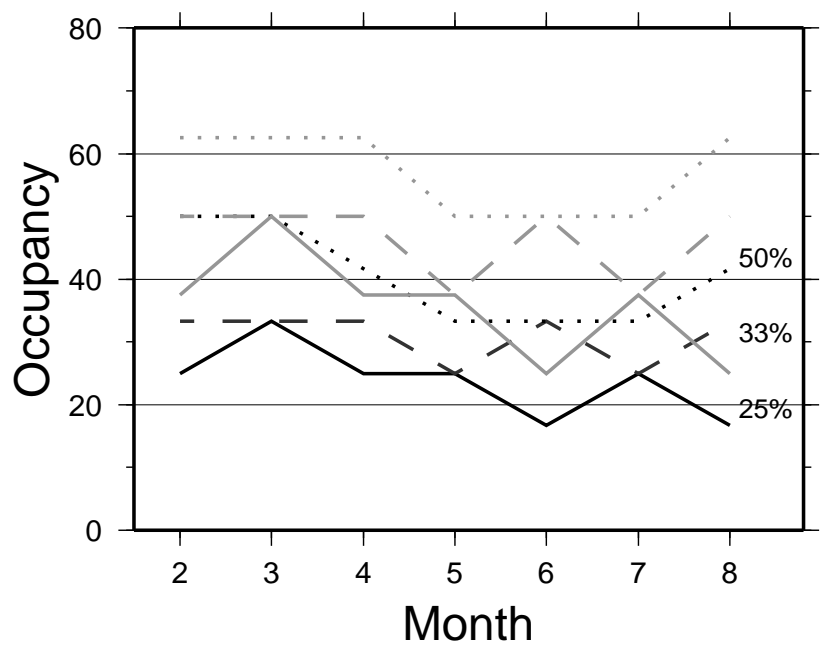

図-3 CGCM 予測実験のアンサンブル平均積算流出量で再現 された渴水年の上位占有率. 対象期間 (1979-2006 年) で 流出量が少ない上位 $25 \%, 33 \%, 50 \%$ 以内にある割合を, 月別に示している. 積算值の定義は図-2に同じ. 図中の 実線, 破線, 点線はそれぞれ, 上位 $25 \%, 33 \%, 50 \%$ の值を 表し, 黒は全期間 (28 年) に対するもの, 灰色は 90 年以降 (17 年) に対する割合を表している.

\section{（2）力学的手法による決定論的季節予測}

上で行った観測值の解析結果から, 冬季からの積算降 水量と 8 月貯水量に関係があるので, 大気-海洋結合モ デルを用いて 8 月貯水量を予測する場合も積算降水量 が適切である. 観測值が利用できなかったため, 調べる ことができなかったが, 貯水湖への積算流入量は, 積算 降水量よりも 8 月貯水量と強い相関があると考えられ る. また, モデルには, 積雪融雪過程も含まれていて, 適 切に流入量 (表面と地中流出量の和) が計算されている と考えられるので, 積算流出量の予測值を用いて以下の 解析を進めた. 対象期間は, CGCM 実験期間の 1979 年 から 2006 年までとする.この間, 1990 年 8 月に渡瀬貯 水池が竣工し, この前後で, 利根川上流 8 ダムの貯水量 容量は, 洪水期に $3.6 \%$, 非洪水期に 5.7\%増加している. ここでは, この前後で, 渴水年発生に有意な差は無いも のと仮定して, 同等に扱う.

今回用いたモデルの日本域における大気現象の再現 性については, 現在現業で用いられている季節予報用大 気モデルよりも良いことが, 調査の結果分かった ${ }^{11}$. 今 回用いている 1 月末から予報した夏 (JJA) の結果では, 東南アジアの循環場が改善し, フィリピン付近から日本 を通りアラスカー向かう波列 (Pacifi c-Japan (PJ)パター ン; 図-4でこの領域に沿って現れる正負の相関パター ンが, PJ パターンの一部を構成している $)^{12)}$ の年々変動 も同様に改善しており, 東南アジアから日本域にかけて, 主な気象要素の予報成績がよくなっている.これは, 結 合モデルで夏の熱帯太平洋西部の降水予測が改善した ためで,十分に詳細な解析を行う価値はあると言える.

全 28 年のうち 12 回の渴水年が, 予測された積算流 出量の少ない上位 25\%,33\%,50\%以内にある割合を月 別に示したのが図-3(黒色線) である. 順位で言い換える 
表-1 1979 年から 2007 年までの渇水年と ENSO 年の関係. 表中の○が渇水年で, ENSO 欄の十と一はそれぞれ, El Niño 年と La Niña 年を表す. ENSO 年の定義については本文を参照. 宣雨欄は 94 年以降の 12 年間の 2-8 月, 6-8 月積算降水量の昇順位 が示されている. 2007 年は対象年に含まれないが, 参考のため加えてある.

\begin{tabular}{|c|c|c|c|c|c|c|c|c|c|c|c|c|c|c|c|}
\hline 年 & 79 & 80 & 81 & 82 & 83 & 84 & 85 & 86 & 87 & 88 & 89 & 90 & 91 & 92 & 93 \\
\hline 渇水 & $\bigcirc$ & $\bigcirc$ & & $\bigcirc$ & & & & & $\bigcirc$ & & & $\bigcirc$ & & & \\
\hline ENSO & & & & + & + & - & - & & + & - & - & & + & + & \\
\hline 年 & 94 & 95 & 96 & 97 & 98 & 99 & 00 & 01 & 02 & 03 & 04 & 05 & 06 & 07 & \\
\hline 渇水 & $\bigcirc$ & & $\bigcirc$ & $\bigcirc$ & & & & $\bigcirc$ & $\bigcirc$ & & $\bigcirc$ & 0 & & & \\
\hline 寡雨 (2-8) & 1 & 8 & 3 & 5 & 11 & 2 & 10 & 4 & 7 & 6 & 9 & 12 & & & \\
\hline 寡雨 (6-8) & 1 & 9 & 3 & 2 & 12 & 4 & 5 & 6 & 10 & 8 & 7 & 11 & & & \\
\hline ENSO & & & & + & + & - & - & & + & & & & & - & \\
\hline
\end{tabular}

と, 渇水年が 7, 9, 14 位以内にある割合である. 予測結果 が, 上位 $X \%$ 以内にランクされた場合, そのカテゴリー で, 渴水年の当たる確率 (的中率または占有率) が $X \%$ を 越えていれば, 予測情報を利用して, 渇水対策を行えば, 毎年渇水対策を行うよりも, 效率的に行うことができる.

3 月の場合, 上位 $25 \%$ には, 12 回の渴水のうち 4 回入っ ている. 即ち, 上位 $25 \%$ に当たる流出量以下の場合, 渴 水と予測すれば, $4 / 12=33 \%$ の確率で当たると言える. 同 じ基準, 上位 25\%で他の月を見ると, 2 月,4 月, 5 月,7 月 は 3 回 (占有率 $25 \%), 6,8$ 月は 2 回 (12.5\%) 入っている. 基準を緩めて, 上位 $33 \%$ とすると, 12 回中, 3 回または 4 回 (25,33\%), 上位 50\% では 4 6 回 (30〜 50\%) であ る. 従って, 3 月からの積算流出量が上位 $25 \%$ 以内にあ るかどうかで, 判断する場合のみ, 季節予測実験結果に 価值があり, その他の場合は全て, アンサンブル平均と しての結果には価值があっても僅かであることを意味 している.

次に, 89 年以前と 90 年以後の 2 期間に分けて, 上位 $33 \%$ てる月がひと月でもある年の数を調べると, 89 年 以前の 4 回の渇水のうちには, 一度も無いが, 90 年以 降の 8 回のうちには, 4 回で上位 $33 \%$ にる月がある. 図-3には, 全 28 年間の結果に加えて, 90 年以降の 16 年 を対象とした場合の結果も示されている. 図中の灰色線 が, 16 年中, 8 回の渴水年が, 積算流出量の少ない上位 25\%,33\%,50\%以内にある割合を示している. 上位 25\% (33\%) に対して的中率は 40\% (45\%) 前後の占有率とな り, 高い確率で渴水年が上位に含まれることが分かる. 90 年代以降に限れば, 全ての上位閾值, 積算期間につい て, 季節予測実駼結果に価值があると言える。

以上の議論では, 取水制限のあった年を渴水年とする, 一般的な定義を用いてきた。 しかし, 深刻な渴水は列島 渴水と言われた 1994 年だけである. 即ち, それ以外の年 の渇水は, 既存の渴水対策を講じることにより, 大きな 支障を来さないように管理することができたと言える. 気象改変が必要な場合は, 1994 年のような甚大な渴水 の場合であろう. 同じ予測值でも, 予測対象が変われば, 予測可能性が変わるので ${ }^{13)}, 1994$ 年のみが予測すべき 渴水年と定義した場合, 決定論的予測が価值があるかを
調べた. 1994 年の予測結果によれば, 3 月以降の積算流 出量は, 全て上位 $25 \%$ 以内にあり, 1994 年の渇水傾向は 予測可能性が高いと言える. 費用対効果面を考えると, 対象とした 28 年間のうち, 上位 $25 \%$ 以内と予測された 年の合計 7 年分のシーディングを行う費用よりも, 1994 年の渴水時に増雪, 増雨によってもたらされる経済効果 が高ければ, 人工気象調節による渇水対策が, 経済的に も有効であったと言える.

\section{4. 議論}

上で示した結果が示す通り, 渴水の力学的手法による 決定論的季節予測は, 容易ではない. ここでは, 予測が 困難である点を ENSO 現象から説明する. まず, 異常 気象や自然災害の遠因として, しばしば取り上げられる ENSO 現象と渴水年の関係を調べ, 次に ENSO 現象と力 学的予測の関係について述べる。

\section{(1) 渴水と ENSO 現象の関係}

表-1 に渴水年 $(\bigcirc)$ と ENSO 年 $(+,-)$ をまとめたもの を示す. 寡雨欄には, 観測值の利用できる 1994 年から 2005 年の 12 年間について, 二つの期間 (2-8 月, 6-8 月) の積算降水量の昇順の順位も示してある. この表での ENSO 年は, 2-8 月の積算降水量と比較するため, 2-8 月 の ENSO 指標時系列を使って定義したのである. 指標 は, 気象庁の定義による, NINO.3 海域 (北緯 5 度〜南緯 5 度, 西経 150 度〜90 度) の月平均 SST の基準值 (その 年の前年までの 30 年間の各月の平均值) と該当月 SST の差の 5 か月移動平均值 ${ }^{14)}$ を用いている. 途中で減衰 のあった, 1995 年夏 1995/96 冬が La Niña 年でなかっ た点だけが,気象庁の通常の定義のものと異なっている.

渴水の発生年は, El Niño 年 8 年中 4 回, La Niña 年 6 年中 0 回, 通常年 14 年中 8 回であった. 渡瀬川流域の みの取水制限のあった $02,04,05$ 年を除くと, El Niño 年 8 年中 3 回, La Niña 年 6 年中 0 回, 通常年 14 年中 7 回 となる. El Niño 年は 8 年中 3,4 回, 通常年は 14 年中 7,8 回と両者に大きな差は無い. しばしば, ENSO 現象は災 


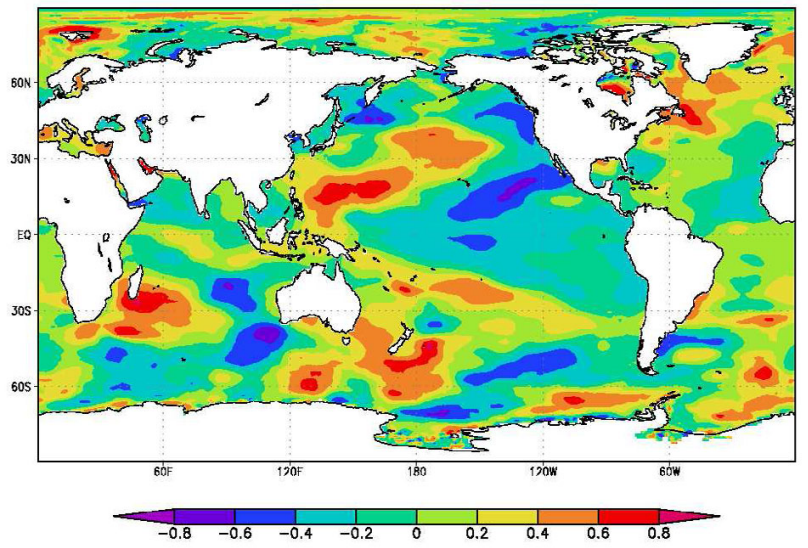

図-4 2-8 月利根川上流域の積算降水量と 2-8 月積算 SST の時 系列相関係数の全球分布. 対象期間 (1994-2005 年). 積算 值の定義は図-2 に同じ. 両側検定の 5\%有意水準は 0.55 .

害の遠因とされるが, 利根川流域の渇水については, 当 てはまらない. 着目す心゙き点は, La Niña 年に全く渇水 が生じていない点である. そこで, 対象期間を 1972 年か らと延長すると, 1973,78 年と La Niña 年に渴水が生じ ている. また, 1996 年は La Niña 年ではないが, 弱い La Niña 傾向が 1 月から 8 月まで続いていた. 従って, 対象 期間の結果だけから, La Niña 年には渴水が生じないあ るいは, 発生頻度が少ないというのは早計であり,この 程度の期間では, どの年も同じ程度の確率で発生し得る と考えるのが妥当である.

図-4に 2-8 月積算の利根川上流域降水量と 2-8 月積 算海面水温 $(\mathrm{SST})$ の年々変動についての相関関係全球 分布図を示す.この図では線形相関を用いていて, 両側 検定 5\%有意水準は 0.55 である. NINO.3 域を始め, 熱 帯東太平洋と相関は低く,これまで議論してきた ENSO 現象と利根川上流域積算降水量のとても弱い関係が再 確認できる.

フィリピン海東部の北半球熱帯西太平洋に相関の高 い領域がある. 利根川上流域の降水量予測には, NINO.3 海域の SST で定義される ENSO 現象よりも,この地域 のSST と比較すべきと考えるかもしれない.この地域 のSST や雲の対流活動と日本の天候の相関が高いこと は良く知られているが, しかし,これらの予測可能性は ENSO 現象によって支配されており, ENSO 現象よりも 低い. 従って, 予測という立場から，この地域のSST と 降水量の関係を調べても有意義な結果は得られない.

\section{(2) ENSO 現象と力学的予測の関係}

以上から, 利根川流域における渴水年と ENSO 年の関 係は無いかあってもとても弱いと言える.このことは， 力学的手法によるアンサンブル平均季節予測に決定的 な意味を持つ. 大気の現象は, 力学的に記述することが できるが, 記述する方程式系は, 非線型な偏微分方程式 のため, 長期予測においては, 初期值に含まれる誤差が 増幅され, 観測誤差程度の誤差によって, いわゆるカオ ス現象 ${ }^{15)}$ により, 全く異なる結果をもたらす. しかし,
そこに，予測期間に亘って, 大気を強制し続ける現象が あれば, 予測結果は, 強制によって決定される予測可能 な成分と強制とは関係のない予測不可能な成分からな ることになる ${ }^{16)}$.アンサンブル平均は, ここで言う，予 測可能な成分を取り出す操作ということができる. 大気 を強制し続ける現象で, 大気よりも低周波で変動するの はSST であり, SST で最も変動が大きく, 予測可能性の 高い現象が ENSO である. この ENSO 現象と渴水に関 係が無いとすれば, 力学的手法に基づくアンサンブル平 均, すなわち決定論的な季節予測は非常に難しいと言わ ざる得ない．

このような事実は, CGCM で SST が完全に予測され たとした場合に相当する観測 SST を与えた大気全球気 候モデル (AGCM) 実験でも示されている. Nakaegawa ら $17,18,19)$ の一連の研究では, 日本域の水資源に関係す る, 降水量, 土壤水分量, 流出量, 河川流量は, アンサン ブル平均をもって予測とする場合, 最大でも全振幅の 50\%程度しか予測できないことが示されており, 前章で 述べた ENSO 現象と渴水の弱い統計関係と図-4 は, こ の理論值を裏付ける観測事実である.

また, 季節予測は, 個々の現象でなく,それらの平均を 主な予測対象とするので, 渇水を解消するような, 台風 や激しい前線活動などがもたらす 1 豪雨を, 予測するこ とも非常に難しい. 個々の現象の再現性から見た場合, こうした点が, 予測可能性を低下させている.

\section{5. まとめ}

首都圈は水資源の多くを利根川上流地域に依存して いる. 本研究は, この地域の夏季渴水対策として, 人工降 雪による水資源量の増加を, より効率的に行うために, 大気一海洋結合モデルを用いた季節予測が有用な情報を もたらすかについて基礎的な検討を行った.

まず, 8 月の平均貯水量とそれに先行する冬季から春 季にかけての予測指標との関係を钼測值から明らかに した. 各月から 8 月までの積算降水量は, 8 月平均貯水 量と 4,5 月からを除き,有意な高い相関関係があった.

次に, 全球大気一海洋結合モデルを用いた力学的な季 節予測実験結果を用いて, 夏季水資源量の予測可能性に ついて検討した. まず, 既往の渴水年が, 定性的に再現さ れているかを調べたところ, アンサンブル平均は, 渇水 傾向をランダムな予測よりも若干良く, 予測していると 言える. また, 90 年以降の渇水の予測精度は, 既往の研 究と同じように ${ }^{20)}$, それ以前に比べて高くなっていた。 また, 甚大な渴水は事例が少なく, 統計的有意性の議論 に馴染まないが, 1994 年の渴水は予測できた可能性が 高かった。

次に, 渴水年と ENSO 年の関係から、得られた結果を 吟味したが, 通常年, El Niño 年, La Niña 年とで有意な 発生確率の差異は見られなく, 定性的に有意な相関関係 を見いだすことができなかった.この結果は力学的手法 
による決定論的な水資源量予測が難しいことを, 観測值 から示したものと言える17,18,19).

豊水年, 渇水年に関わらず, 毎年人工降雪による水資 源量の増加を実施すると, 夏季になって水資源が潤沢で あれば, 余分な貯水は利用されずに放水される. 非効率 ではあるが,これでも費用対効果で十分採算が合うので あれば, 実用的である.しかし, 本研究の結果によれば, 毎年必ず人工気象調節の降雪シーディングを実施する よりも, 3 月からの積算流出量を判断材料として, 渴水 傾向にあると予測された年だけに実施することにより， 費用対効果が若干高まることが期待される.今後は, 人 工降雨・降雪による水資源量の増加対策を始めとした 渇水対策に掛かる費用とその効果を, 予測の空振りを含 めて検討し, 経済的にも十分に採算が合うかを提示する ことが, 必要であろう。

謝辞 : 本研究は, 文部科学省科学振興調整費「渇水対策 のための人工降雨・降雪に関する総合的研究」(代表: 気 象研究所 村上正隆) による支援を受けて行われた. 利根 川ダム関連データは, 国土交通省関東地方地方整備局か ら提供を受けたもので, この資料収集にはいであ (株) 吉 田, 越田両氏に協力いただいた. また、村上正隆博士に は、この論文原稿に対して雲物理的観点から的確な意 見を頂いた。

結合モデルによる季節予測実験は, 気象研究所融合型 経常研究「大気海洋結合季節予測モデルとそのアンサ ンブル手法の開発に関する研究」の下で, 世界気候研究 計画の季節予報タスクフォース ( The WCRP Task Force on Seasonal Prediction (TSFP)) の国際共同研究に参加す るために行われた. 同じく融合型経常研究「日本の異常 気象の実態及び気候変動との関連に関する研究」の下 で, 異常気象と渴水の関連性について調査する機会を得 た.ここに, 有意義な議論をしてくださった, これらプロ ジェクト参加者に感謝致します。

最後に, この論文に対して建設的かつ適切なコメント を下さった 3 名の査読者に感謝致します.

\section{参考文献}

1) IPCC, editor. IPCC Fourth Assessment Report, chapter 11. Regional Climate Projections, pp. 847-940. Cambridge University press, 2007.

2) K. Kamiguchi, A. Kitoh, T. Uchiyama, R. Mizuta, and A. Noda. Changes in precipitation-based extremes indices due to global warming projected by a global $20-\mathrm{km}$-mesh atmospheric model. SOLA, Vol. 2, pp. 64-67, 2006.

3) 村上正隆. 人工降雪による水資源確保の可能性について. 気像, Vol. 514, pp. 16462-16468, 2000.

4) 村上正隆, 折笠成宏, 楠研一, 星本みずほ, 小菅博, 池田明 弘. 水資源確保を目的とした人工降雪技術の現状. 第 5 回 水資源シンポジウム, 第 5 巻, pp. 575-580, 乃木坂、日本 学術会議, 2002.

5) M. Murakami, N. Orikasa, M. Hoshimoto, K. Kusunoki, H. Kosuge, and H. Ikeda. Present state of japanese research on orographic snow cloud modification for water resources augmentation. In Preprints The 8th WMO Scientific Conference on Weather Modification, WMO Report, No. 36, pp. 95-98. WMO, 1999.

6) 安田珠幾, 高谷祐平, 松本聡. 気象庁/気象研季節予報用大 気海洋結合モデル. 平成 18 年度全国季節予報技術検討会 資料, pp. 69-78, つくば市, 2007.

7) 佐藤信夫, 里田弘. 生物圏と大気圈の相互作用. 数值予報 課報告, 気象庁予報部, 1989 .

8) K. Onogi, J. Tsutsui, H. Koide, M. Sakamoto, S. Kobayashi, H.i Hatsuhika, T. Matsumoto, N. Yamazaki, H. Kamahori, K. Takahashi, S. Kadokura, K. Wada, K. Kato, R. Oyama, T. Ose, N. Mannoji, and R. Taira. The JRA-25 Reanalysis. J. Meteor. Soc. Jpn., Vol. 85, pp. 369-432, 2007.

9) N. Usui, S. Ishizaki, Y. Fujii, H. Tsujino, T. Yasuda, and M. Kamachi. Meteorological research institute multivariate ocean variational estimation (MOVE) system: Some early results. Advances in Space Research, Vol. 37, pp. 806-822, 2006.

10) 村上正隆, 星本みずほ, 折笠成宏, 山田芳則, 水野量, 徳野 正己, 添田耕一, 梶川正弘, 池田弘明, 伍井稔. 冬期越後山 脈にかかるシーダビリティの高い雪雲の出現頻度: 衛星 赤外チャンネルデータとマイクロ波放射計データを用い た 統計的評価. 天気, Vol. 48, No. 8, pp. 547-559, 2001.

11) T. Yasuda, Y. Takaya, C. Kobayashi, M Kamachi, H Kamahori, and T Ose. Asian Monsoon predictability in JMA/MRI seasonal forecast system. In CLIVER Exchanges, pp. 18-24, Southampton, U.K., 2007.

12) T. Nitta. Convective activities in the tropical western Pacific and their impact on the Northern Hemisphere summer circulation. J. Meteor. Soc. Jpn., Vol. 65, pp. 373-390, 1987.

13) T. N. Palmer, F.J. Doblas-Reyes, R. Hagedorn, and A. Weisheimer. Probabilistic prediction of climate using multi-model ensembles: from basics to applications. Philo. Trans. Roy. Soc.(B), Vol. 360, pp. 1991-1998, 2005.

14) 気象庁. エルニーニョ/ラニーニャ現象. http://www.data. jma.go.jp/gmd/cpd/elnino/, 2007 年 9 月 30 日アクセス.

15) E. N. Lorenz. Atmospheric predictability experiments with a large numerical model. Tellus, Vol. 34, pp. 505-513, 1982.

16) J. Shukla. A predictability in the midst of chaos: A scientific basis for climate forecasting. Science, Vol. 282, pp. 728731, 1998.

17) 仲江川敏之, 楠昌司, 杉正人, 鬼頭 昭雄 小林ちあき, 高野 清治. 全球大気モデルを用いた季節予報実験に基づく水 資源量の予測精度と予測可能性. 水工学論文集, Vol. 46, pp. 109-114, 2002.

18) 仲江川敏之, 保坂征宏. 力学的アンサンブル手法による熱 帯アジアモンスーン地域の河川流量の潜在的季節予測可 能性. 水工学論文集, Vol. 50, pp. 523-528, 2006.

19) T. Nakaegawa, S. Kusunoki, M. Sugi, A. Kitoh, C. Kobayashi, and K. Takano. A study of dynamical seasonal prediction of potential water resources based on an atmospheric gcm experiment with prescribed sea-surface temperature. Hydrol. Sci. J., Vol. 52, No. 1, pp. 152-165, 2007.

20) T. Nakaegawa, M. Kanamitsu, and T. M. Smith. Interdecadal trend of prediction skill in an ensemble AMIP-type experiment. J. Climate, Vol. 17, No. 14, pp. 2881-2889, 2004.

(2007.9.30 受付) 